\title{
Ion nitriding of TiNi shape memory alloys I. Nitriding parameters and microstructure characterization
}

\author{
S.K. Wu *, C.L. Chu, H.C. Lin ${ }^{1}$ \\ Institute of Materials Science and Engineering, National Taiwan University, Taipei 106, Taiwan
}

Received 2 January 1997; accepted 10 March 1997

\begin{abstract}
$\mathrm{Ti}_{50} \mathrm{Ni}_{50}$ and $\mathrm{Ti}_{50} \mathrm{Ni}_{40} \mathrm{Cu}_{10}$ shape memory alloys were ion nitrided to modify the surface conditions. The phases and microstructures of the nitrided surface were studied by XRD, EPMA and SEM. Experimental results indicate that the nitrided compound layer of equiatomic TiNi alloy consists of $\mathrm{TiN}$ and $\mathrm{Ti}_{2} \mathrm{Ni}$ phases, and that of $\mathrm{Ti}_{50} \mathrm{Ni}_{40} \mathrm{Cu}_{10}$ alloy consists of $\mathrm{TiN}$, $\mathrm{Ti}_{2} \mathrm{~N}$ and $\mathrm{Ti}_{40}(\mathrm{Ni}, \mathrm{Cu})_{60}$ phases. The surface hardness and the compound layer thickness increase with increasing nitriding temperature and time. These nitrided compound layers are found to exhibit a slight depression on the alloys' martensitic transformation temperatures and their shape recovery ability. A mechanism to explain the formation of the ion-nitrided layer in equiatomic TiNi alloy is also proposed in this study. (C) 1997 Elsevier Science S.A.
\end{abstract}

Keywords: Shape memory alloys; Ion nitriding; TiNi alloys

\section{Introduction}

TiNi alloys are known as the most important shape memory alloys (SMAs) because they exhibit thermoelastic martensitic transformation, and because of their many applications based on the shape memory effect (SME) [1] and pseudoelasticity (PE) [2,3]. This comes from the fact that TiNi alloys have superior properties in ductility, biocompatibility and recoverable strain. Recently, TiNi alloys have been observed to exhibit an excellent wear resistance [4-6], which is an important property in some biomedical applications, such as medical guide-wires, artificial bone joints, etc. In fact, the B2 phase (austenite parent phase) of TiNi alloys can really exhibit an excellent wear resistance due to their rapid work hardening and pseudoelastic properties [7]. However, the wear resistance of $\mathrm{B} 19^{\prime}$ martensite phase of TiNi alloys is still too weak and needs to be improved for some applications. It is well known that nitriding techniques are commonly used to improve the fatigue and wear resistance of metals and alloys [8]. In particular, ion nitriding has a number of advantages over conventional gas nitriding, including faster growth rates

\footnotetext{
* Corresponding author.

${ }^{1}$ Present address: Department of Materials Science, Feng Chia University, Taichung 400, Taiwan.
}

of nitrided layers, easier control over the crystal structure of nitrided layers, and fewer environmental problems [9]. Several investigations on ion nitriding have been performed for titanium and titanium alloys [10-22], but so far there have been few investigations on TiNi alloys. Only the effects of $\mathrm{N}^{+}$implantation [23] and arc ion plating [24] on TiNi alloys have been reported. In the present study, the ion nitriding of TiNi alloys is investigated. The nitriding parameters and the characteristics of the nitrided layers are discussed as the first part of this paper. The corrosion properties and the primary wear characteristics of the nitrided layers are discussed as the second part of this paper.

\section{Experimental procedures}

A conventional tungsten arc melting technique was employed to prepare the $\mathrm{Ti}_{50} \mathrm{Ni}_{50}$ and $\mathrm{Ti}_{50} \mathrm{Ni}_{40} \mathrm{Cu}_{10}$ (in at.\%) alloys. Titanium (purity 99.7\%), nickel (purity 99.9\%) and copper (purity 99.9\%), totalling $200 \mathrm{~g}$, were melted and remelted at least six times in an argon atmosphere. Pure titanium buttons were also melted and used as getters. The mass loss during melting was negligible. The as-melted buttons were homogenized at $1050^{\circ} \mathrm{C}$ in a $7 \times 10^{-6}$ torr vacuum furnace for 3 days and then hot-rolled at $850^{\circ} \mathrm{C}$ to a plate of $1 \mathrm{~mm}$ 
thickness. Specimens with dimensions of $10 \times 20 \times 1 \mathrm{~mm}$ were then cut from the plate using a low speed diamond saw. A hole, $2.5 \mathrm{~mm}$ in diameter, was drilled in each specimen by electrical discharge machining. This hole was used to hang the specimen during the ion nitriding. The specimen surface was then polished with 1000 grit emery paper. Before ion nitriding, all specimens were cleaned ultrasonically in acetone to remove surface grease.

Ion nitriding was carried out in a NDK furnace model JIN-6SS-C-SV. The specimen's support and holder were made of titanium to reduce contamination of the specimen surface during the sputtering process. After nitriding, the specimens were cooled in vacuum. In order to investigate the relationship between treatment parameters and surface properties, four treatment parameters were considered: nitriding temperature; nitriding time; working pressure; and nitrogen-to-hydrogen ratio $\left(\left[\mathrm{N}_{2}\right] /\left[\mathrm{H}_{2}\right]\right.$ ratio). The standard $\mathrm{L} 9$ orthogonal arrays [25] of these four parameters used in this study are listed in Table 1.

The microstructures of nitrided layers were studied by X-ray diffraction (XRD) and scanning electron microscopy (SEM). XRD tests were carried out on a Philips PW1710 XRD using $\mathrm{Cu} \mathrm{k}_{\alpha}$ radiation. The power was $40 \mathrm{kV} \times 30 \mathrm{~mA}$ and the $2 \theta$ scanning rate was $3^{\circ} \mathrm{min}^{-1}$. The surface morphologies and cross-section of ion-nitrided samples were observed by a Philips 515 SEM with EDX facility. The chemical composition of surface layers was analyzed using a JEOL JXA-8600SX electron probe microanalyzer (EPMA) with a probe size $1 \mu \mathrm{m}$. The surface hardness was tested with a microvickers tester with a load of $25 \mathrm{~g}$ for $15 \mathrm{~s}$. For each specimen, at least five different locations were tested. The DSC measurement was conducted to measure the martensitic transformation temperatures by using a DuPont 2000 thermal analyzer equipped with a quantitative scanning system 910 DSC cell and a cooling accessory LNCA II. Measurements were carried out at a controlled cooling/ heating rate of $10^{\circ} \mathrm{C} \mathrm{min}-1$. Heats of transformation $(\Delta H)$ were automatically calculated from the areas under

Table 1

Nitriding parameters employed in the standard L9 orthogonal arrays

\begin{tabular}{lllll}
\hline $\begin{array}{l}\text { Experimental } \\
\text { no, of L9 }\end{array}$ & $\begin{array}{l}\text { Nitriding } \\
\text { temperature } \\
\left({ }^{\circ} \mathrm{C}\right)\end{array}$ & $\begin{array}{l}\text { Nitriding } \\
\text { time } \\
(\mathrm{h})\end{array}$ & $\begin{array}{l}\text { Working } \\
\text { pressure } \\
\text { (torr) }\end{array}$ & $\begin{array}{l}{\left[\mathrm{N}_{2}\right] /} \\
{\left[\mathrm{H}_{2}\right]} \\
\text { ratio }\end{array}$ \\
\hline 1 & 700 & 2 & 6 & 10 \\
2 & 700 & 4 & 8 & 4 \\
3 & 700 & 12 & 10 & 1 \\
4 & 800 & 2 & 8 & 1 \\
5 & 800 & 4 & 10 & 10 \\
6 & 800 & 12 & 6 & 4 \\
7 & 900 & 2 & 10 & 4 \\
8 & 900 & 4 & 6 & 1 \\
9 & 900 & 12 & 8 & 10 \\
\hline
\end{tabular}

DSC peaks by means of an equipment software package. The shape memory effect (SME) was examined by a bending test [26]. The surface bending strain, $\epsilon_{\mathrm{s}}$, was $8 \%$ and the shape recovery, $R_{\mathrm{SME}}$, was measured at various heating temperatures, $T_{\mathrm{f}}$.

\section{Results and discussion}

\subsection{Microstructures and composition analysis of ion- nitrided $T i_{50} \mathrm{Ni}_{50}$ alloy'}

After ion nitriding, $\mathrm{Ti}_{50} \mathrm{Ni}_{50}$ specimens show a homogeneous surface morphology with a color of golden yellow. The homogeniety and surface roughness are dependent on the nitriding parameters, as shown in Figs. 1 ( $a$ and $b$ ). Figs. 2( $a-d$ ) shows the XRD patterns of $\mathrm{Ti}_{50} \mathrm{Ni}_{50}$ specimens without and with ion nitriding at 700,800 and $900^{\circ} \mathrm{C}$ for $12 \mathrm{~h}$, respectively. Before ion nitriding, as shown in Fig. 2(a), main B19' martensite and minor $B 2$ parent phase are the major phases in the $\mathrm{Ti}_{50} \mathrm{Ni}_{50}$ matrix. However, after nitriding, as shown in Figs. 2(b-d), TiN and compounds are the main phases in the XRD patterns. The intensities of $\mathrm{TiN}$ and $\mathrm{Ti}_{2} \mathrm{Ni}$ compounds increase with increasing nitriding temperature as well as nitriding time. This indicates that the thickness of $\mathrm{TiN}$ and $\mathrm{Ti}_{2} \mathrm{Ni}$ compounds increases with increasing nitriding temperature and nitriding time. Because the hardnesses of $\mathrm{TiN}$ and $\mathrm{Ti}_{2} \mathrm{Ni}$ compounds are much higher than that of $\mathrm{Ti}_{50} \mathrm{Ni}_{50}$ matrix, the surface hardnesses of nitrided $\mathrm{Ti}_{50} \mathrm{Ni}_{50}$ specimens are quite high, as shown in Fig. 3. Meanwhile, the surface hardness, being related to the thickness of $\mathrm{TiN}$ and $\mathrm{Ti}_{2} \mathrm{Ni}$ compounds, increases with increasing nitriding temperature and nitriding time. The surface hardness can even reach $1400 \mathrm{Hv}$ for the experimental no. 9 specimen of L9-nitrided $\mathrm{Ti}_{50} \mathrm{Ni}_{50}$ specimens.

Typical cross-section micrographs of $\mathrm{Ti}_{50} \mathrm{Ni}_{50}$ specimens ion nitrided at $900^{\circ} \mathrm{C}$ for 4 and $12 \mathrm{~h}$ are shown in Figs. 4( $a$ and $b$ ), respectively. On carefully examining Fig. 4, two different layers, an outer layer labeled $A$ and an inner layer labeled B, are formed on the surface of nitrided $\mathrm{Ti}_{50} \mathrm{Ni}_{50}$ specimens. In addition, some fine $\mathrm{Ti}_{4} \mathrm{Ni}_{2} \mathrm{O}[27,28]$ particles introduced during the melting process are observed, as indicated by the arrows in the matrix.

These nitrided layers are the compound layers as is often seen in nitrided pure titanium and its alloys [10 22]. As observed from the XRD patterns in Fig. 2, these nitrided layers should be $\mathrm{TiN}$ and $\mathrm{Ti}_{2} \mathrm{Ni}$ compound layers. The concentration profiles of $\mathrm{Ti}, \mathrm{Ni}$ and $\mathrm{N}$ in these nitrided layers of $\mathrm{Ti}_{50} \mathrm{Ni}_{50}$ specimens were examined by EPMA. In order to obtain a precise composition analysis, the surface of the mounted specimens was carefully polished without any etching. Fig. 5 shows the EPMA line scan of $\mathrm{Ti}_{50} \mathrm{Ni}_{50}$ specimen nitrided at 

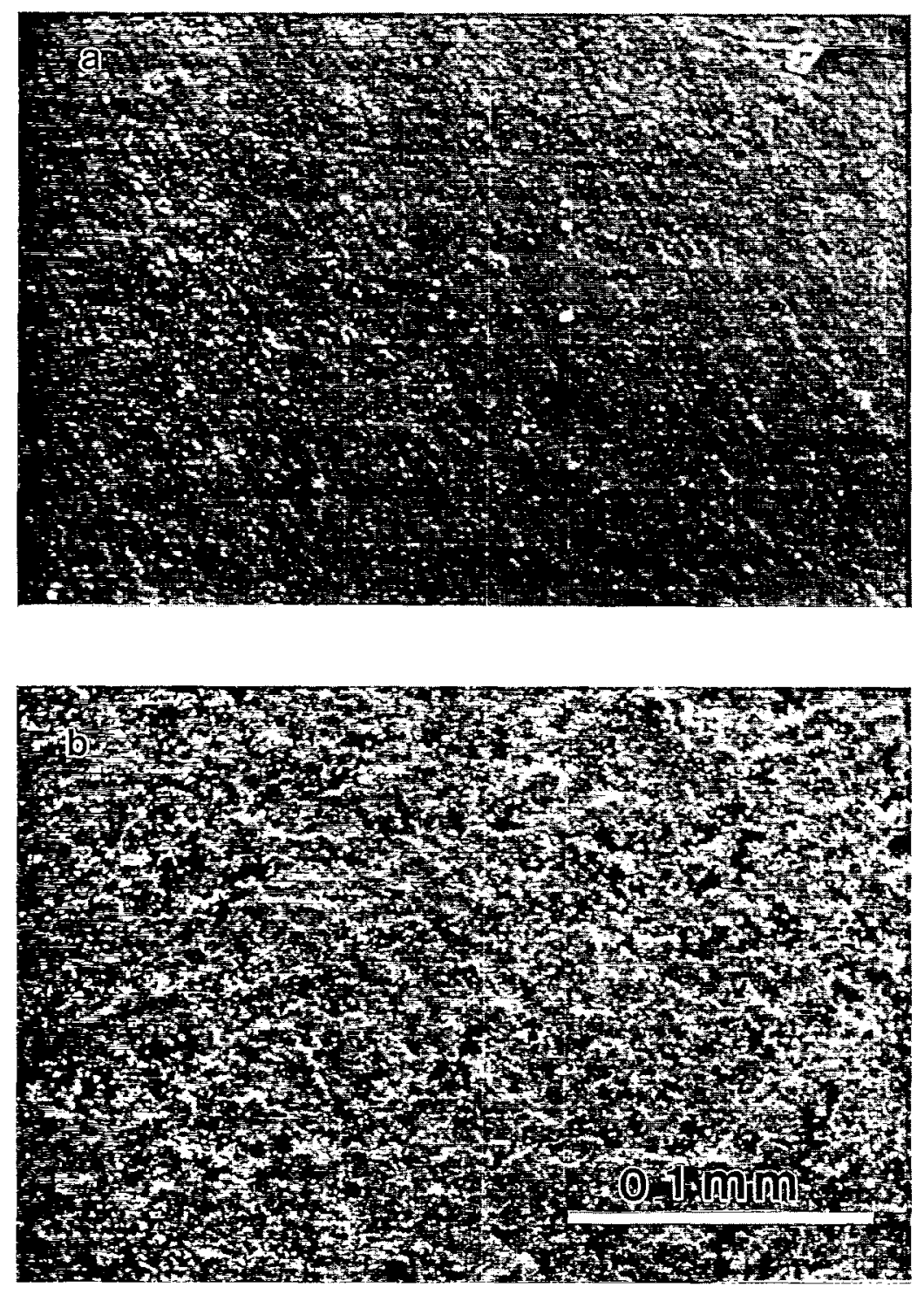

Fig. 1. Scanning electron micrographs of surface morphology of equiatomic TiNi alloy after ion nitriding at $900{ }^{\circ} \mathrm{C}$ for (a) $4 \mathrm{~h}$ and (b) $12 \mathrm{~h}$.

$900^{\circ} \mathrm{C} \times 12 \mathrm{~h}, 8$ torr and $\left[\mathrm{N}_{2}\right] /\left[\mathrm{H}_{2}\right]=10$. The intensity of the $\mathrm{Nk}_{\alpha}$ line increases from the surface to a maximum at the position of the outer compound layer (layer $\mathrm{A}$ ). It then decreases continuously through the $B$ layer and levels off in the interface of the B layer and TiNi matrix. It is difficult to confirm the existance of nitrogen diffusion layer in the substrate from Fig. 5 because of the rare concentration of nitrogen in the TiNi matrix. The intensity of the $\mathrm{Ti}_{\alpha}$ line also increases from the surface to a maximum at the $A$ layer, and then gradually decreases through the $B$ layer and levels off at the interface of the $\mathrm{B}$ layer and the TiNi matrix. The intensity of the $\mathrm{Ni} \mathrm{k}_{\alpha}$ line in A layer is rather weak. It continuously increases in the B layer and then levels off at the interface of the $B$ layer and the TiNi matrix. From the results of XRD in Fig. 2 and the variations of $\mathrm{Ti}, \mathrm{Ni}$ and $\mathrm{N}$ concentrations in Fig. 5, we propōose that a TiN compound forms in the $A$ layer and a
$\mathrm{Ti}_{2} \mathrm{Ni}$ compound forms in the $\mathrm{B}$ layer. From Fig. 5, one can find that the $\mathrm{Ti}_{2} \mathrm{Ni}$ layer can solid-solute quite a few nitrogen atoms, but the TiNi layer behaves oppositely.

\subsection{Microstructures and composition analysis of ion- nitrided $\mathrm{Ti}_{50} \mathrm{Ni}_{40} \mathrm{Cu}_{10}$ alloy}

The $\mathrm{Ti}_{50} \mathrm{Ni}_{40} \mathrm{Cu}_{10}$ ternary alloys have also been ion nitrided at the same nitriding process as that for equiatomic TiNi alloys in order to compare their ion-nitriding behaviors with binary $\mathrm{Ti}_{50} \mathrm{Ni}_{50}$ alloys. Figs. 6(a-d) shows the XRD patterns of $\mathrm{Ti}_{50} \mathrm{Ni}_{40} \mathrm{Cu}_{20}$ specimens without and with ion nitriding at 700,800 and $900{ }^{\circ} \mathrm{C}$ for $12 \mathrm{~h}$, respectively. Before ion nitriding, as shown in Fig. 6(a), B19+B19' martensite and B2 parent phase are the major phases in the $\mathrm{Ti}_{50} \mathrm{Ni}_{40} \mathrm{Cu}_{10}$ matrix. This explains the fact that $\mathrm{Ti}_{50} \mathrm{Ni}_{40} \mathrm{Cu}_{10}$ alloys exhibit 

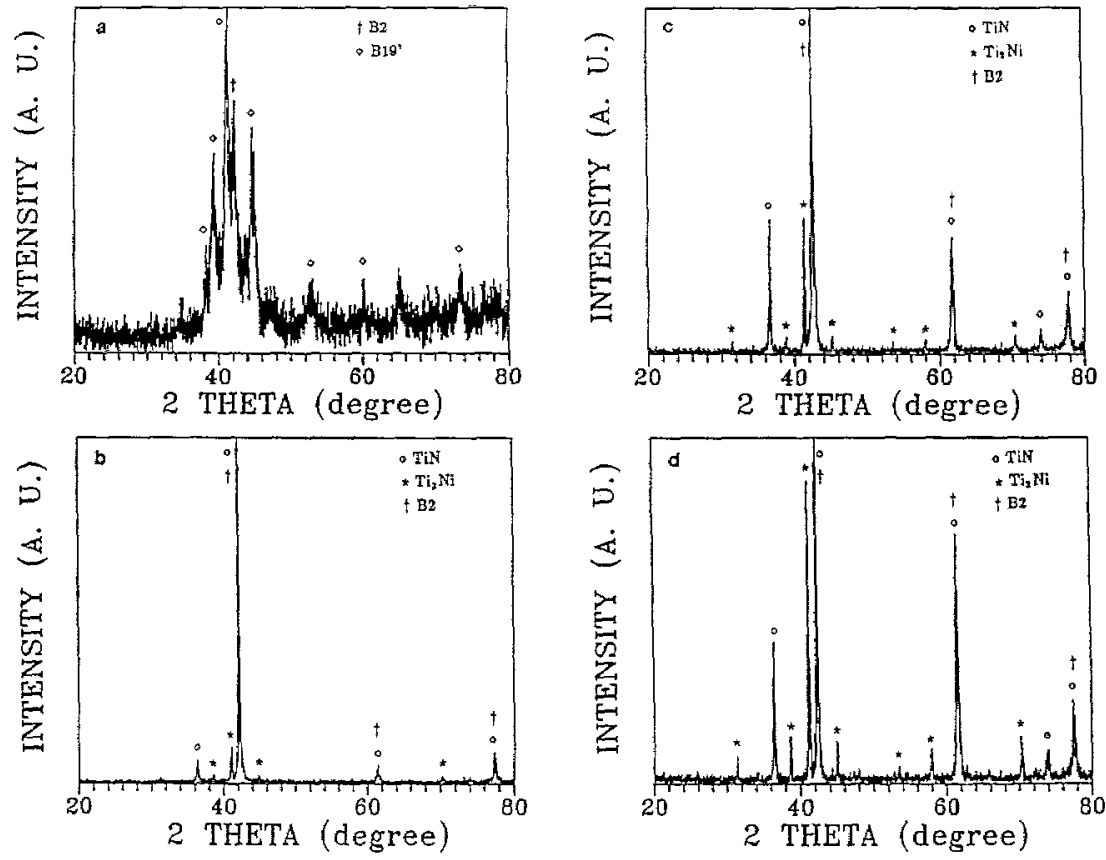

Fig. 2. XRD patterns of equiatomic TiNi specimens (a) without ion nitriding, and ion nitrided at (b) $700^{\circ}$, (c) $800^{\circ} \mathrm{C}$ and (d) $900^{\circ} \mathrm{C}$ for $12 \mathrm{~h}$.

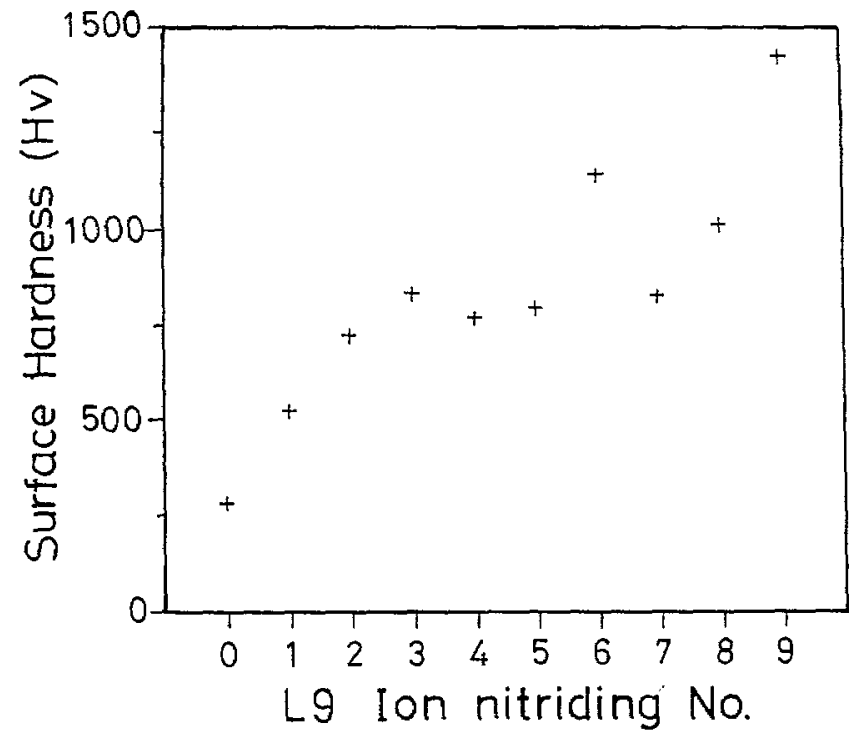

Fig. 3. The surface hardness of equiatomic TiNi alloy ion nitrided at various conditions of Table 1.

$\mathrm{B} 2 \rightarrow \mathrm{B} 19 \rightarrow \mathrm{B} 19^{\prime}$ martensitic transformation, and martensitic transformation temperatures of $\mathrm{B} 2 \rightarrow \mathrm{B} 19$ and $\mathrm{B} 19 \rightarrow \mathrm{B} 19^{\prime}$ occur at around room temperature [29]. However, after nitriding, as shown in Figs. 6(b-d), the peaks of $\mathrm{TiN}, \mathrm{Ti}_{2} \mathrm{Ni}$ and $\mathrm{Ti}_{40}(\mathrm{Ni}, \mathrm{Cu})_{60}$ compounds appear in the XRD patterns. Here, the chemical composition of $\mathrm{Ti}_{40}(\mathrm{Ni}, \mathrm{Cu})_{60}$ compound is quantified by EPMA and is regarded as a new phase. The peak intensities of these compounds increase with increasing nitriding temperature as well as nitriding time. This indicates that the thickness of these compounds increases with increasing nitriding temperature and nitriding time. This feature can also be observed in Figs. 7 (a and $b$ ), which shows the cross-section micrographs of $\mathrm{Ti}_{50} \mathrm{Ni}_{40} \mathrm{Cu}_{10}$ specimens ion nitrided at $900^{\circ} \mathrm{C}$ for 4 and $12 \mathrm{~h}$, respectively. In Fig. 7, three different layers, labeled $\mathrm{A}, \mathrm{B}$ and $\mathrm{C}$, are formed on the surface of nitrided $\mathrm{Ti}_{50} \mathrm{Ni}_{40} \mathrm{Cu}_{10}$ specimens. The concentration profiles of $\mathrm{Ti}, \mathrm{Ni}, \mathrm{Cu}$ and $\mathrm{N}$ in these nitrided layers of $\mathrm{Ti}_{50} \mathrm{Ni}_{40} \mathrm{Cu}_{10}$ specimens have been examined by EPMA, and a typical line scan is shown in Fig. 8. The intensity of the $\mathrm{N} \mathrm{k}_{q}$ line increases from the surface to a maximum at the A layer, then decreases continuously through the $B$ layer, and levels off at the interface of the $B$ and $C$ layers. The intensity of the $T i k_{\alpha}$ line also increases from the surface to a maximum at the $A$ layer and then gradually drops through the $B$ layer, reaching a minimum at the interface of the $B$ and $C$ layers. The intensity then increases a little and levels off at the interface of the $\mathrm{C}$ layer and $\mathrm{Ti}_{50} \mathrm{Ni}_{40} \mathrm{Cu}_{10}$ matrix. The intensity of the $\mathrm{Ni} \mathrm{k}_{\gamma}$ line in the A layer is rather weak. It increases continuously at the interface of the $A$ and $B$ layers, through the $\mathrm{B}$ and $\mathrm{C}$ layers, and then levels off at the interface of the $\mathrm{C}$ layer and the $\mathrm{Ti}_{50} \mathrm{Ni}_{40} \mathrm{Cu}_{10}$ matrix. The intensity of the $\mathrm{Cu} \mathrm{k}_{\alpha}$ line in the $\mathrm{A}$ and $\mathrm{B}$ layers is also rather weak. It increases rapidly to a maximum at the $\mathrm{C}$ layer, then decreases continuously and levels off at the interface of the $C$ layer and the $\mathrm{Ti}_{50} \mathrm{Ni}_{40} \mathrm{Cu}_{10}$ matrix. From the results of XRD in Fig. 6 and the variations of $\mathrm{Ti}, \mathrm{Ni}, \mathrm{Cu}$ and $\mathrm{N}$ concentrations in Fig. 8, we propose that $\mathrm{TiN}, \mathrm{Ti}_{2} \mathrm{Ni}$ and $\mathrm{Ti}_{40}(\mathrm{Ni}, \mathrm{Cu})_{60} \mathrm{com}-$ pounds form in the $\mathrm{A}, \mathrm{B}$ and $\mathrm{C}$ layers, respectively. It should be noted that the $\mathrm{Ti}_{2} \mathrm{Ni}$ layer can solve more $\mathrm{Cu}$ atoms than the TiN layer. 

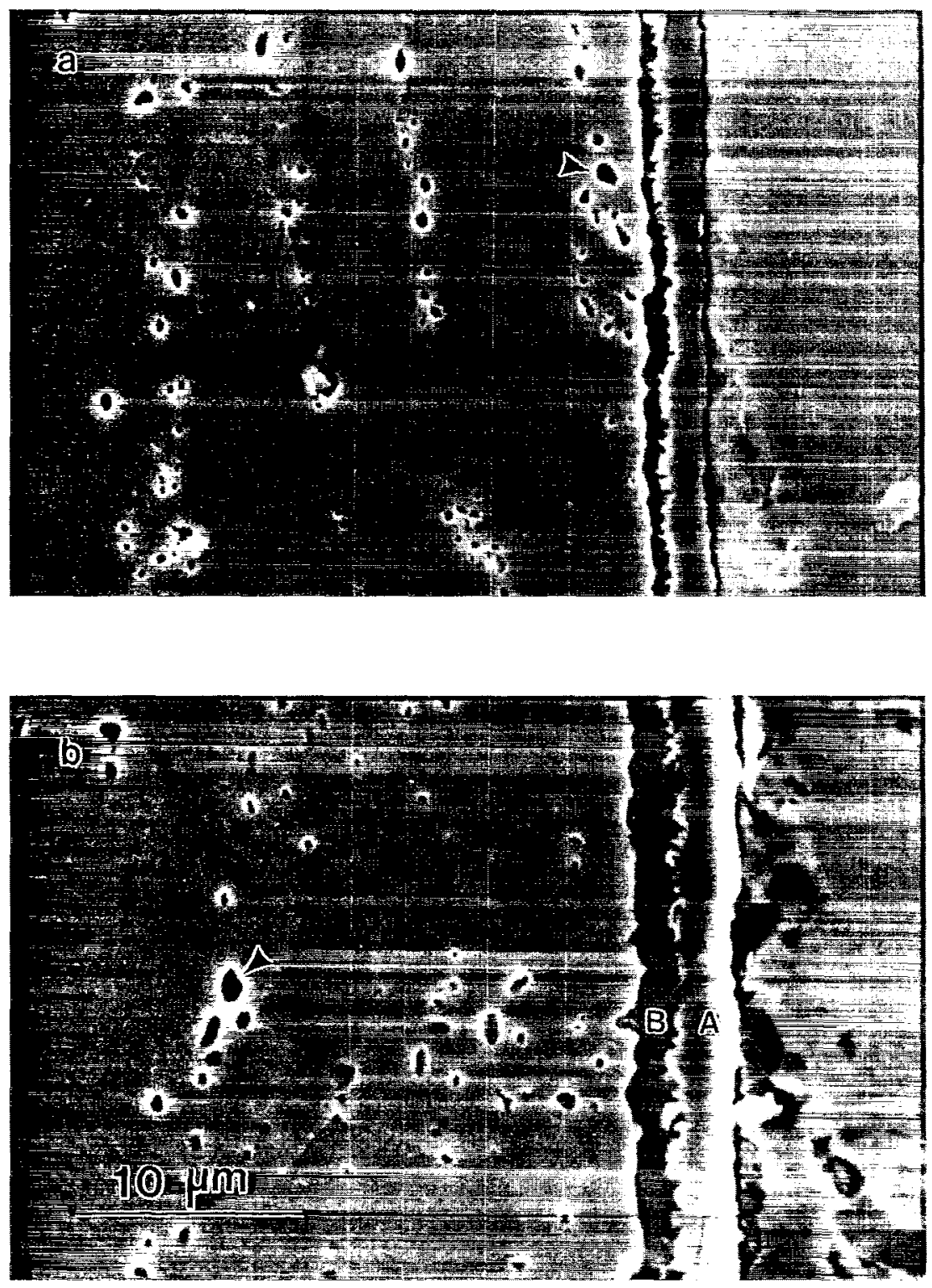

Fig. 4. Scanning electron micrographs of cross-sections of equiatomic TiNi alloy after ion nitriding at $900^{\circ} \mathrm{C}$ for (a) $4 \mathrm{~h}$ and (b) $12 \mathrm{~h}$.

\subsection{Ion-nitriding mechanism in equiatomic TiNi shape memory alloy}

The detailed reaction mechanism in the ion-nitriding process has not been clarified yet; however, two mechanisms has been proposed to explain the ion-nitriding process in steels $[30,31]$. The first mechanism proposes sputtering of $\mathrm{Fe}$ atoms, gasous reaction and then deposition on the specimen. The second mechanism proposes a surface reaction and then diffusion of nitrogen into the specimen. To explain the ion-nitriding reaction in equiatomic TiNi alloy, we propose the fourstep mechanism shown in Fig. 9. When the $\mathrm{N}^{+}$ions hit the surface of a workpiece, metal atoms ( $\mathrm{Ti}$ and $\mathrm{Ni}$ ) are detached and the workpiece is heated. At the same time, nonmetallic atoms such as carbon and oxygen are also detached. In this way, the surface is freed from oxides, carbides etc., allowing $\mathrm{N}^{+}$ions to be sputtered onto the clean surface [Fig. 9(I)]. $\mathrm{Ti}$ and $\mathrm{Ni}$ atoms which are detached from the surface can react with the highly reactive nitrogen atoms, which are sputtered in the plasma region or implanted on the surface of workpiece. Because the chemical affinity of $\mathrm{Ti}$ and $\mathrm{N}$ is much stronger than that of $\mathrm{Ni}$ and $\mathrm{N}$ [32], the combination of a $\mathrm{N}^{+}$ion and a Ti atom occurs more easily than that of $\mathrm{a} \mathrm{N}^{+}$ion and a $\mathrm{Ni}$ atom. This means that the material formed on the workpiece surface is composed of a much greater amount of TiN than $\mathrm{Ni}_{x} \mathrm{~N}$, as shown in layer $\mathrm{A}$ of Fig. 9(II). We believe that the $\mathrm{Ni}_{x} \mathrm{~N}$ phase was not found in the XRD results of Fig. 2 because the amount of $\mathrm{Ni}_{x} \mathrm{~N}$ is too small to be detected. As the process continues, the sputtered $\mathrm{N}^{+}$ions at layer $\mathrm{A}$ of 


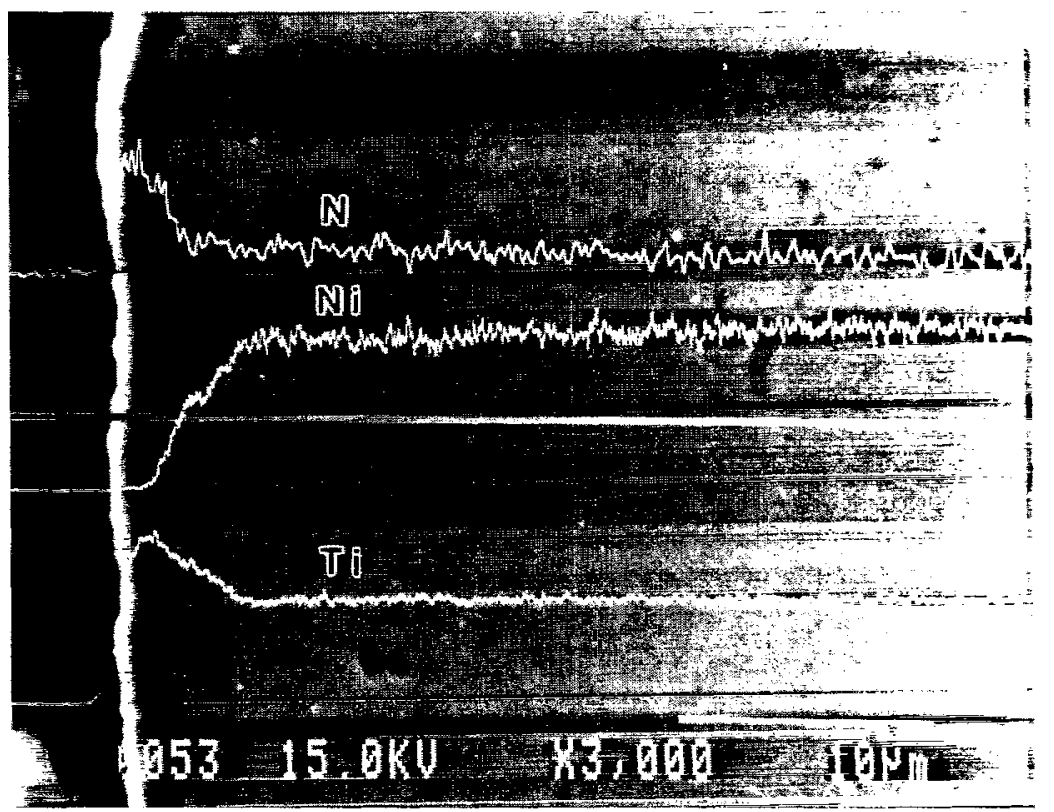

Fig. 5. EPMA line scan profiles of equiatomic TiNi alloy ion nitrided at $900^{\circ} \mathrm{C} \times 12 \mathrm{~h}, 8$ torr and $\left[\mathrm{N}_{2}\right] /\left[\mathrm{H}_{2}\right]=10$.
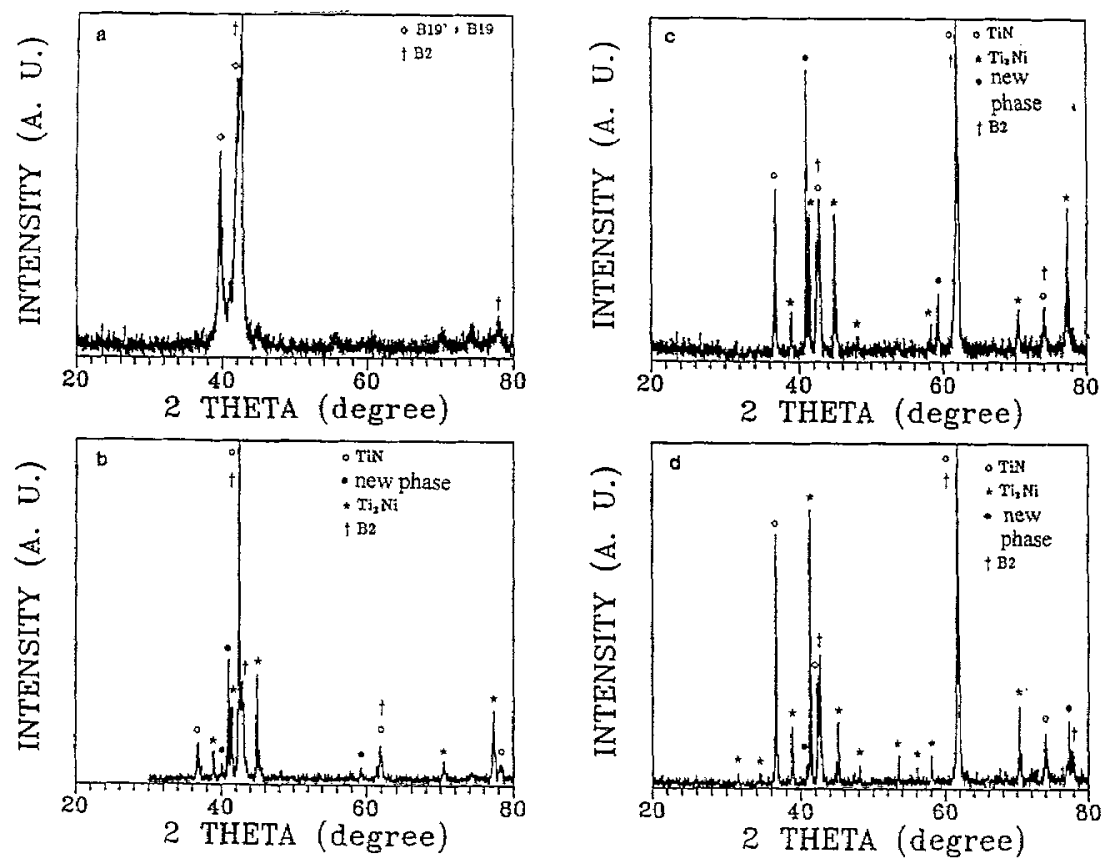

Fig. 6. XRD patterns of $\mathrm{Ti}_{50} \mathrm{Ni}_{40} \mathrm{Cu}_{10}$ specimens (a) without ion nitriding, and ion nitrided at (b) $700{ }^{\circ} \mathrm{C}$, (c) $800^{\circ} \mathrm{C}$ and (d) $900^{\circ} \mathrm{C}$ for $12 \mathrm{~h}$.

Fig, 9(III) diffuse inwards. The $\mathrm{Ti}$ atoms can react more easily with $\mathrm{N}^{+}$because the chemical affinity of $\mathrm{Ti}$ and $\mathrm{N}$ is stronger than that of $\mathrm{Ni}$ and $\mathrm{N}[32]$. Thus, there is an outward driving force for Ti atoms which, together with the inward movement of $\mathrm{N}^{+}$ions, forms TiN and thickens layer A. Meanwhile, the outward Ti atoms left behind layer $A$ will react with $\mathrm{TiNi}$ to form $\mathrm{Ti}_{2} \mathrm{Ni}$ compound layer B [Fig. 9(IV)]. When the ion-nitriding temperature increases, the diffusion rates of $\mathrm{Ti}$ atoms and $\mathrm{N}^{+}$ions also increase, and hence the TiN and $\mathrm{Ti}_{2} \mathrm{Ni}$ layers grow more rapidly and the XRD intensities of these phases become stronger, as shown in Figs. 2 and 4 . When the TiN in layer A (Fig. 9) reaches a certain thickness, it can become a barrier [33,34] and subsequently reduce the diffusion of $\mathrm{N}^{+}$ions into the $\mathrm{Ti}_{2} \mathrm{Ni}$ compound layer. This feature also reflects the fact that the undetectable nitrogen concentration at the rear part of the B layer and the TiNi matrix. 

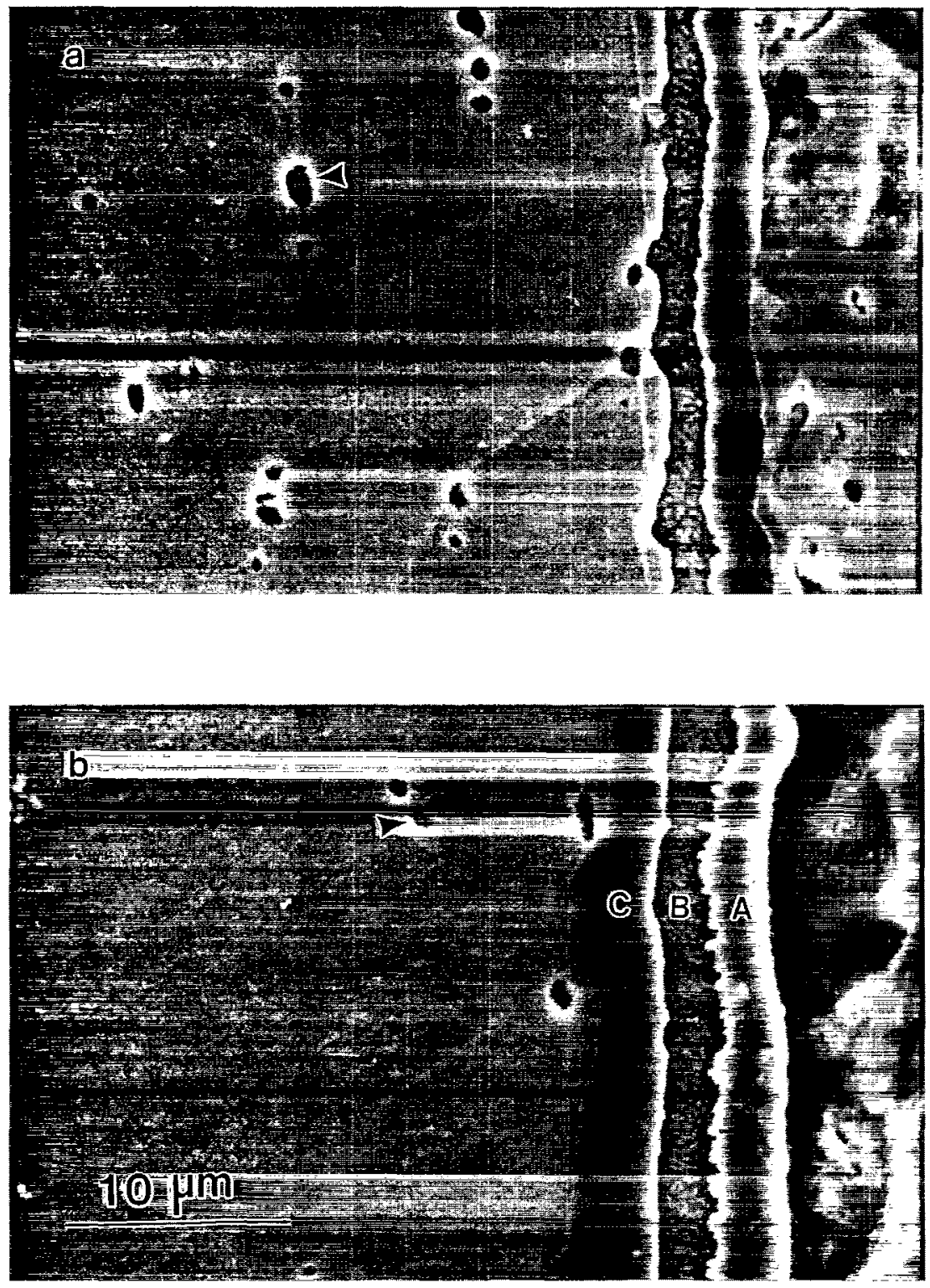

Fig. 7. Scanning electron micrographs of cross-sections of $\mathrm{Ti}_{50} \mathrm{Ni}_{40} \mathrm{Cu}_{10}$ ternary alloys after ion nitriding at $900{ }^{\circ} \mathrm{C}$ for (a) $4 \mathrm{~h}$ and (b) $12 \mathrm{~h}$.

\subsection{Effects of ion nitriding on the transformation temperatures and shape recovery ability of the equiatomic TiNi alloy}

Figs. $10(\mathrm{a}-\mathrm{c})$ shows the DSC curves of $\mathrm{Ti}_{50} \mathrm{Ni}_{50}$ specimens without and with ion nitriding at $800^{\circ} \mathrm{C}$ for 4 and $12 \mathrm{~h}$, respectively. Fig. 10(a) represents a typical DSC curve of a stress-free $\mathrm{Ti}_{50} \mathrm{Ni}_{50}$ alloy in which the exothermic and endothermic peaks are associated with the martensitic transformation of $\mathrm{B} 2 \leftrightarrow \mathrm{B} 19^{\prime}$. The DSC curves for the ion-nitrided specimens, as shown in Figs. 10(b and c), exhibit similar martensitic transformation behaviors. However, the martensitic transformation temperatures are depressed to lower ones. This phenomenon may be ascribed to two factors. First, the constrained stress originating from the ion-nitrided layers will depress the martensitic transformation. Second, the penetration of $\mathrm{N}$ atoms or other impurities into the TiNi matrix as the interstitial atoms during the ion-nitriding process also have the possibility to depress the transformation temperatures [35].

Table 2 presents the measured shape recovery, $R_{\mathrm{SME}}$, at heating temperatures of $T_{\mathrm{f}}=100$ and $300^{\circ} \mathrm{C}$ for the ion-nitrided equiatomic TiNi alloy. From Table 2, the shape recovery is found to be slightly reduced due to the ion nitriding. This result is reasonable because the nitrided compound layers do not exhibit the shape memory effect and their constrained effect on the TiNi matrix will also depress the shape recovery of TiNi matrix. 


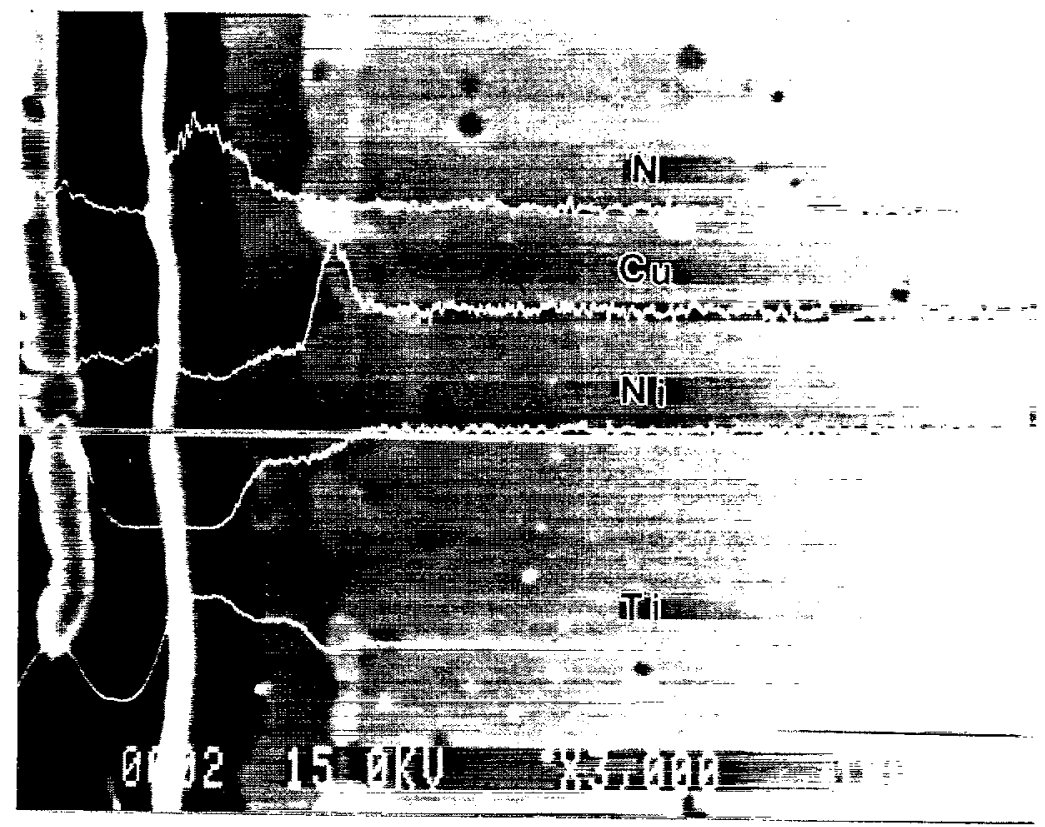

Fig. 8. EPMA line scan profiles of $\mathrm{Ti}_{50} \mathrm{Ni}_{40} \mathrm{Cu}_{10}$ ternary alloy ion nitrided at $900^{\circ} \mathrm{C} \times 12 \mathrm{~h}, 8$ torr and $\left[\mathrm{N}_{2}\right] /\left[\mathrm{H}_{2}\right]=10$.

(1) SPUTTERING \& IMPLANTATION

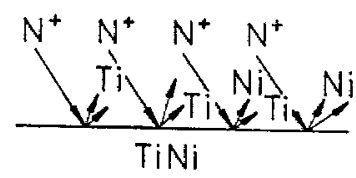

(II) TIN FORMATION

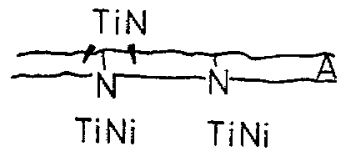

(III) DIFFUSION

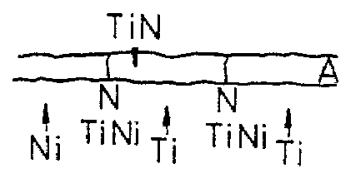

(IV) REACTION \& GROWTH

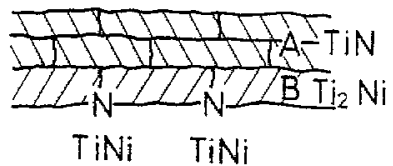

Fig. 9. Schematic diagram of the ion nitriding mechanism of equiatomic TiNi alloy.

\section{Conclusions}

The ion nitriding of $\mathrm{Ti}_{50} \mathrm{Ni}_{50}$ and $\mathrm{Ti}_{50} \mathrm{Ni}_{40} \mathrm{Cu}_{10}$ shape memory alloys has been investigated. The results obtained by means of microvickers hardness test, XRD, SEM and EPMA measurements can be summarized as follows:

(1) The ion nitrided equiatomic TiNi alloy consists

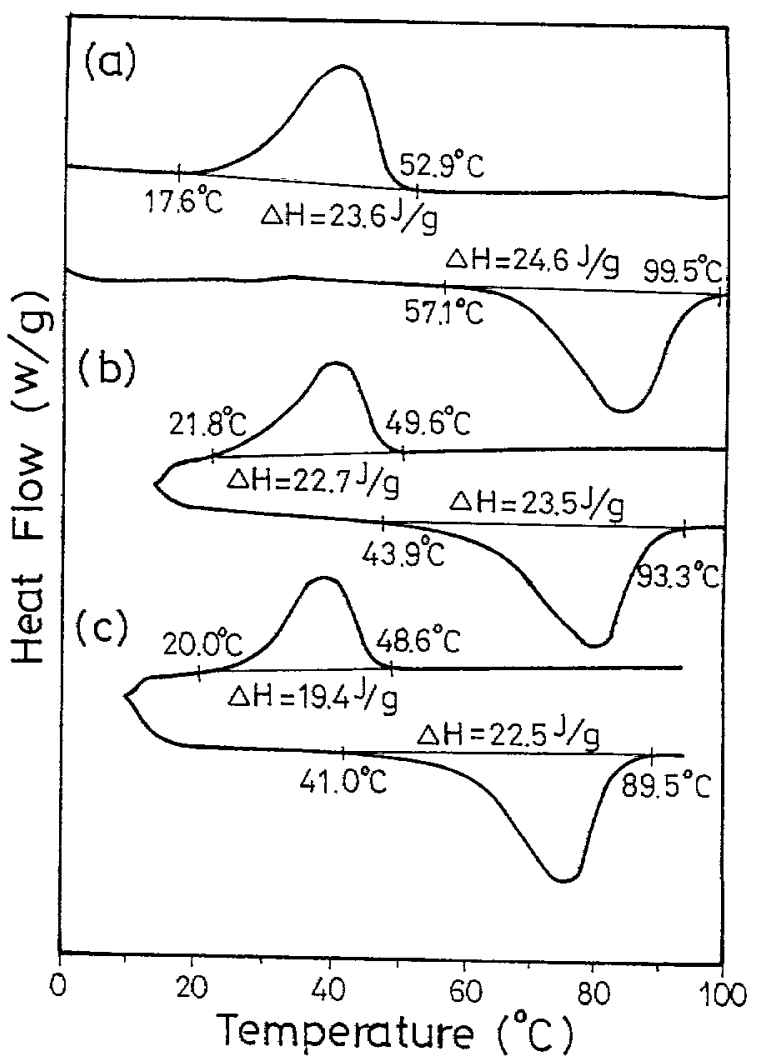

Fig. 10. The DSC curves of equiatomic TiNi specimens (a) without ion nitriding, and ion nitrided at $800^{\circ} \mathrm{C}$ for (b) $4 \mathrm{~h}$ and (c) $12 \mathrm{~h}$.

of the $\mathrm{TiN}$ and $\mathrm{Ti}_{2} \mathrm{Ni}$ phases in the compound layer. The surface hardness, ascribed to the thickness of TiN and $\mathrm{Ti}_{2} \mathrm{Ni}$ compound layer, increases with increasing nitriding temperature and time. For the ion nitrided $\mathrm{Ti}_{50} \mathrm{Ni}_{40} \mathrm{Cu}_{10}$ ternary alloy, the $\mathrm{Ti}_{40}(\mathrm{Ni}, \mathrm{Cu})_{60}$ com- 
Table 2

The measured shape recovery, $R_{\mathrm{SME}}$, at heating temperatures of $T_{\mathrm{f}}=$ $300^{\circ} \mathrm{C}$ for the ion-nitrided equiatomic TiNi alloys

\begin{tabular}{|c|c|c|}
\hline \multirow{2}{*}{$\begin{array}{l}\text { Experimental } \\
\text { no. of L9 }\end{array}$} & \multirow{2}{*}{$\frac{\text { Shape recovery }}{T_{\mathrm{f}}=100^{\circ} \mathrm{C}}$} & \multirow{2}{*}{$\frac{R_{\mathrm{SME}}(\%)}{T_{i}>300^{\circ} \mathrm{C}}$} \\
\hline & & \\
\hline None ${ }^{a}$ & 100.0 & 100.1 \\
\hline 1 & 87.9 & -94.4 \\
\hline 2 & 78.2 & 85.5 \\
\hline 3 & 75.3 & 81.5 \\
\hline 4 & 76.6 & 83.2 \\
\hline 5 & 76.1 & 81.0 \\
\hline 6 & 74.8 & 80.5 \\
\hline 7 & 75.8 & 81.2 \\
\hline 8 & 74.4 & 79.2 \\
\hline 9 & 73.5 & 78.6 \\
\hline
\end{tabular}

${ }^{\mathrm{a} B e f o r e ~ i o n ~ n i t r i d i n g ~}$

pound, as well as $\mathrm{TiN}$ and $\mathrm{Ti}_{2} \mathrm{Ni}$ phases, appear in the ion-nitrided layers.

(2) The ion-nitriding mechanism of equiatomic TiNi alloy is suggested to include several simultaneous steps: the sputtering of titanium and nickel from the surface, the formation of TiN, the diffusion of $\mathrm{N}^{+}$ions into the matrix, the reaction of $\mathrm{Ti}$ and $\mathrm{N}^{+}$to form $\mathrm{TiN}$, and the reaction of $\mathrm{Ti}$ and $\mathrm{TiNi}$ to form $\mathrm{Ti}_{2} \mathrm{Ni}$.

(3) The martensitic transformation temperatures are depressed slightly due to the constrained stress originating from the ion-nitrided layers. At the same time, the ion-nitrided layers exhibiting no shape memory effect and behaving the constrained effect on the substrate will both depress slightly the shape recovery ability of TiNi alloys.

\section{Acknowledgement}

The authors are pleased to acknowledge the financial support of this research by the National Science Council (NSC), Republic of China under Grant No. NSC 84-2216-E002-027.

\section{References}

[1] S. Miyazaki, K. Otsuka, Y. Suzuki, Scripta Metall. 15 (1981) $287-292$
[2] S. Miyazaki, Y. Ohmi, K. Otsuka, Y. Suzuki, ICOMAT-82, J. Phys. 43 (1982) 255-260.

[3] S. Miyazaki, T. Imai, Y. Igo, K. Otsuka, Metall. Trans. A 17A (1986) $115-120$.

[4] J.L. Jin, H.L. Wang, Acta Metall. Sinica 24 (1988) A66-69.

[5] D.Y. Li, Scripta Metall, 34 (1996) 195-200.

[6] P. Clayton, Wear 162-164 (1993) 202-210.

[7] H.M. Liao, H.C. Lin, J.L. He, K.C. Chen, K.M. Lin, Proceedings of the International Conference on Displacive Transformations, 1996, in press.

[8] ASM Handbook, vol. 4, 9th ed, American Society for Metals, Metals Park, OH, 1991, p. 387.

[9] W. Kovacs, W. Russell, Proceedings of the ASM International Conference on Ion Nitriding, American Society for Metals, Metals Park, OH, 1986, p. 9.

[10] L.H. Chang, L.K. Lee, H.C. Peng, C.Y. Wang, Acta Metall. Sin. 20 (1984) A221-A228.in Chinese

[11] A. Raveh, P.L. Hansen, R. Avni, A. Grill, Surf. Coatings Technol. 38 (1989) 339-351.

[12] E. Metin, O.T. Inal, Metall. Trans. A 20 (1989) 1819-1823.

[13] E. Metin, O.T. Inal, Mater. Sci. Engng Al45 (1991) 65-77.

[14] E. Metin, Scr. Metall. 26 (1992) 1193-1197.

[15] H.J. Brading, P.H. Morton, T. Bell, L.G. Earwaker, Surf. Engng 8 (1992) 206-212.

[16] A. Ravech, R. Avni, A. Grill, Thin Solid Films 186 (1990) $241-256$.

[17] F.M. Kustas, M.S. Misra, R. Wei, P.J. Wilbur, J.A. Knapp, Surf. Coat. Technol. 51 (1992) 100-105.

[18] P. Scradi, B. Tesi, T. Bacci, C. Gianoglio, Surf. Coatings Technol. 41 (1990) 83-91.

[19] K.T. Rie, T. Lampe, Mater. Sci. Engng 69 (1985) 473-481.

[20] E. Rolinski, Mater. Sci. Engng 100 (1988) 193-199.

[21] R. Avni, T. Spalvins, Mater. Sci. Engng 95 (1987) 237-246.

[22] C.L. Chu, S.K. Wu, Surf. Coatings Technol. 78 (1996) 211-226.

[23] P. Moine, O. Popoola, Scripta Mat. 20 (1986) 305-310.

[24] K. Endo, R. Sachdeva, Y. Araki, H. Phno, Proceedings of the International Conference on Shape Memory and Superelastic Technologies, SMST-94, 1994, pp. 233-237.

[25] P.J. Ross, Taguchi Techniques for Quality Engineering, McGrawHill, New York, 1988, p. 23.

[26] H.C. Lin, S.K. Wu, Scr. Metall. Mater. 26 (1992) 59-62.

[27] P. Duwez, J.L. Taylor, AIME Trans. 188 (1950) 1173.

[28] G.M. Michal, Diffusionless Transformation in TiNi, Ph.D thesis, Stanford University, CA, 1979.

[29] Y.C. Lo, S.K. Wu, H.E. Horng, Acta Metall. Mater. 41 (1993) $747-759$.

[30] B. Edenhofer, Heat Treat. Metals 1 (1974) 23-26.

[31] T. Spalvins, Proceedings of the ASM International Conference on Ion Nitriding, American Society for Metals, Metals Park, $\mathrm{OH}$, 1986, p. 1.

[32] C.E. Wicks, F.E. Block, Thermodynamic Properties of 65 Elements - Their Oxides, Halides, Carbides, and Nitrides, US Government Printing Office, Washington, DC, 1963, pp. 13-124.

[33] M. Wittmer, Appl. Phys. Lett. 36 (6) (1980) 456-458.

[34] M. Wittmer, Appl. Phys. Lett. 37 (6) (1980) 540-542.

[35] T. Honma, Shape Memory Alloys, Gordon and Breach, Amsterdam, 1987, pp. 89-101. 